\title{
EFFECT OF SINGLE CELL PROTEIN AS A PROTEIN SOURCE IN DROSOPHILA CULTURE
}

\author{
Handan Uysal*; M. Nuri Aydogan; O. Faruk Algur \\ Department of Biology, Faculty of Science and Arts, Atatürk University, Erzurum, Turkey.
}

Submitted: May 27, 2002; Approved: December 10, 2002

\begin{abstract}
The effects of biomass of Phanerochaete chrysosporium at various concentrations $(1 ; 2.5 ; 5 ; 10 ; 25 ; 50 ; 75$ and $100 \%$ ) on the growth of Drosophila melanogaster have been investigated. Biomass was used as a protein source instead of corn flour in Standard Drosophila Medium(SDM). It was seen that it causes increments in both body size of larvae and the numbers of offsprings, especially at higher concentrations (50, 75 and $100 \%$ ). At the application of $100 \%$ concentration, metamorphosis accelerated and was completed one day before the control. There were phenotipic abnormalities in both control $(0.64 \%)$ and applications with low concentrations (0.02-0.19\%), while they were not observed at the application of $100 \%$ concentration
\end{abstract}

Key words: Single cell protein, toxicity, Drosophila, Phanerochaete chrysosporium

\section{INTRODUCTION}

Use of microbes as a food source may appear to be unacceptable to some people but the idea of consumption of microbes as food for man and animals is certainly innovative to solve the global food problem. Algae, fungi and bacteria are the chief of microbial protein (single cell protein- SCP) that can be utilized as a protein supplement $(2,7)$. Many fungal species are used as a protein-rich food. They provide the B-complex group of vitamines and they also show a low level of nucleic acid content (8). The amino acid composition of Aspergillus niger according to FAO standards is well balanced (11). Yeast contains thiamine, riboflavin, biotin, niacin, pantothenic acid, pyridoxine, choline, streptogenin, glutathione, folic acid and Pamino benzoic acid (8). SCP from mixed cultures of Trichoderma reesei and Kluyveromyces marxianus are reported to contain essential amino acids which compares favorably with FAO guidelines and soybean oil meal (9). But, it was also reported that SCP should also pass all toxicity tests to be commercialized as a food product. Some fungal secondary metabolites such as patulin, citrinin, ochratoxin A, roquefortine, rubratoxin B and penicillic acid may cause acute and chronic toxicity, especially to the kidney and liver tissues of rat, guinea pigs, mice and cockerels $(4,12,13)$. Some extracts and metabolites of Aspergillus and Penicillium decreased survival of the larvae of Drosophila hydei and prolonged their development $(5,10)$. Penicillium roqueforti filtrate increased the mortality of $\mathrm{F}_{1}$ generation of $D$. melanogaster (17).

The aim of this research is to investigate the availability of SCP of Phanerochaete chrysosporium as a protein source and its possible toxic effects in Drosophila culture.

\section{MATER1ALS AND METHODS}

\section{Organism}

Drosophila melanogaster Meig (Diptera: Drosophilidae) Oregon- $\mathrm{R}$ strain was used in this investigation. This is a laboratory wild type stock adopted into laboratory conditions by intermating for a long time. For the growth and stock cultures, Standart Drosophila Medium (SDM) was used (17). The stocks were maintained in an incubator adjusted to $25 \pm 1^{\circ} \mathrm{C}$ and 40 $60 \%$ relative humidity.

White-rot fungus, Phanerochaete chrysosporium (ATCC 28236), was used for SCP production. The organism was maintained by subculturing on Sabouraud Dextrose Agar Slants for 14 days at $37^{\circ} \mathrm{C}$ and then stored at $4^{\circ} \mathrm{C}$.

All media and chemicals used in this study were analytical grade.

* Corresponding author. Mailing address: Department of Biology, Faculty of Science and Arts, Atatürk University, Erzurum, Turkey 


\section{PRODUCTION OF SCP}

Fermentation was carried out in a bench top fermenter (BIOSTAT M). During this operation, aeration, agitation and temperature were adjusted to $1 \mathrm{vvm}, 600 \mathrm{rpm}$ and $35^{\circ} \mathrm{C}$, respectively. An aliquot of $10 \mathrm{ml}$ of $P$. chrysosporium spore suspension with approximatelly $5 \times 10^{7}$ spores from slant culture was transferred to a $250 \mathrm{ml}$ flask containing $100 \mathrm{ml}$ of nutrient broth. This flask was incubated for 72 hours with continuous shaking $(250 \mathrm{rpm})$. The contents of the flask were transferred to the fermenter vessel containing 21 of nutrient broth. Foaming was controlled manually using an antifoam (Fluka chemie. AG, CH-9470 Buchs). Stationary phase mycelia were harvested by filtration through a 80 -mesh copper sieve and thoroughly washed with distilled water. The mycelia were dried at $60^{\circ} \mathrm{C}$, ground in a mortar to a very fine powder and kept desiccated (6). Protein determination of the biomass was carried out by the microkjeldahl method. Dry matter and total ash content of biomass were determined using the standard methods outlined in AOAC (3). The amino acid analysis of the biomass was carried out by automatic amino acid analyser (Biotronic LC 5001) after hydrolysis of the sample protein in 6N HCL for 24 hours (1).

\section{Experimental Groupings}

To test the effects of the SCP on the growth of $D$. melanogaster, this species was cultivated in 9 different media, shown in Table 1. One female and three male flies with the same age were put into each of culture vials. All of the females used in the experiments were virgin. The developmental stages were followed daily. After pupa formation, the parental individuals were removed. Offsprings were counted everyday from the first day of eclosion and the sexes were noted.

Table 1. The composition of different media used for this study.

\begin{tabular}{|c|c|c|c|c|c|}
\hline \multirow[b]{2}{*}{ Medium } & \multirow[b]{2}{*}{$\begin{array}{c}\text { SCP } \\
\text { concentration } \\
\% \\
\end{array}$} & \multicolumn{4}{|c|}{ Composition } \\
\hline & & $\begin{array}{l}\text { SCP } \\
\text { (gr) }\end{array}$ & $\begin{array}{l}\text { Corn flour } \\
\text { (gr) }\end{array}$ & $\begin{array}{c}\text { Agar } \\
\text { (gr) }\end{array}$ & $\begin{array}{c}\text { Base } \\
\text { solution } \\
(\mathrm{ml})^{*}\end{array}$ \\
\hline I & - & - & 2.23 & 0.5 & 30 \\
\hline II & 1 & 0.02 & 2.21 & 0.5 & 30 \\
\hline III & 2.5 & 0.06 & 2.17 & 0.5 & 30 \\
\hline IV & 5 & 0.11 & 2.12 & 0.5 & 30 \\
\hline V & 10 & 0.22 & 2.00 & 0.5 & 30 \\
\hline VI & 25 & 0.56 & 1.67 & 0.5 & 30 \\
\hline VII & 50 & 1.11 & 1.11 & 0.5 & 30 \\
\hline VIII & 75 & 1.67 & 0.56 & 0.5 & 30 \\
\hline IX & 100 & 2.23 & - & 0.5 & 30 \\
\hline
\end{tabular}

*: Base solution contains $106.19 \mathrm{~g}$ sucrose and $31 \mathrm{~g}$ yeast in 1 liter of distilled water.
All experiments were done in triplicate. Chi- square test was used for the statistical analysis of the results. Statistical comparisons are between experimental groups and the control.

\section{RESULTS AND DISCUSSION}

Proximate composition of the biomass of $P$. chrysosporium is shown in Table 2. Values in this table are similar to the composition obtained by using other fungi $(1,6,14)$.

The detailed amino acid composition of obtained biomass and of FAO reference protein are given in Table 3. Biomass obtained from P. chrysosporium contained all of the essential amino acids. It is rich in lysine. Primary limiting amino acids are the sulphur containing ones. Because tryptophane is destroyed during the acid hydrolysis, this amino acid is not reported.

SCP accelerated the metamorphosis especially at higher concentrations. In all of the control and experimental groups, except for $100 \%$ application, laid egg, first, second and third instar larvae, prepupae, pupae and adult individuals were observed at the days of $2^{\text {nd }}, 3^{\text {rd }}, 4^{\text {th }}, 5^{\text {th }}, 6^{\text {th }}, 7^{\text {th }}$ and $9^{\text {th }}$, respectively.

Table 2. Approximate composition of the biomass of $P$. chrysosporium.

\begin{tabular}{cc}
\hline Components & $(\mathrm{g} / 100 \mathrm{~g}$ of dry matter $)$ \\
Dry matter & 94.2 \\
Total ash & 8.1 \\
Total nitrogen & 5.42 \\
Crude protein & 33.9 \\
\hline
\end{tabular}

Table 3. Amino acid composition of protein of $P$. chrysosporium and FAO reference protein.

\begin{tabular}{ccc}
\hline Amino acids $(\mathrm{g} / 100 \mathrm{~g})$ & P. chrysosporium & FAO \\
\hline Aspartic acid & 11.25 & - \\
Threonine & 3.29 & 2.8 \\
Serine & 4.11 & - \\
Glutamic acid & 18.56 & - \\
Proline & 3.33 & - \\
Glycine & 6.22 & - \\
Alanine & 4.98 & - \\
Cysteine & 0.97 & 2.0 \\
Valine & 5.02 & 4.2 \\
Methionine & 1.88 & 2.2 \\
Isoleucine & 4.17 & 4.2 \\
Leucine & 8.00 & 4.8 \\
Tyrosine & 4.00 & 2.8 \\
Histidine & 3.05 & - \\
Lucine & 6.55 & 4.2 \\
Tryptophan & - & 1.4 \\
\hline
\end{tabular}


However, in the application of $100 \%$ concentration (Medium IX), first adult was observed at the $8^{\text {th }}$ day after mating. That is, metamorphosis was completed one day ago in this medium. On the other hand, it was also observed that the body sizes of larvae of experimental groups, especially of 75 and $100 \%$ concentrations, were bigger than those of control (Fig. 1).

The number of offsprings increased with the increasing of SCP (Table 4). For example, the total numbers of offsprings for media I (Control), II and IX were found to be 770, 1550 and 5060, respectively. The differences in the numbers of male-female individuals between the control and experimental groups were not statistically significant $(\mathrm{P}>0.05)$, while the increasing of the total number of offsprings was significant $(\mathrm{P}<0.01)$. We also examined the phenotipic abnormalities of $\mathrm{F}_{1}$ individuals for all media and we found that there were phenotipic abnormalities (in respect of wing, thorax and body size) in both control (abnormality: $0.64 \%$ ) and the media with low concentrations $(1 ; 2.5 ; 5 ; 10 ; 25 \%)$ of SCP

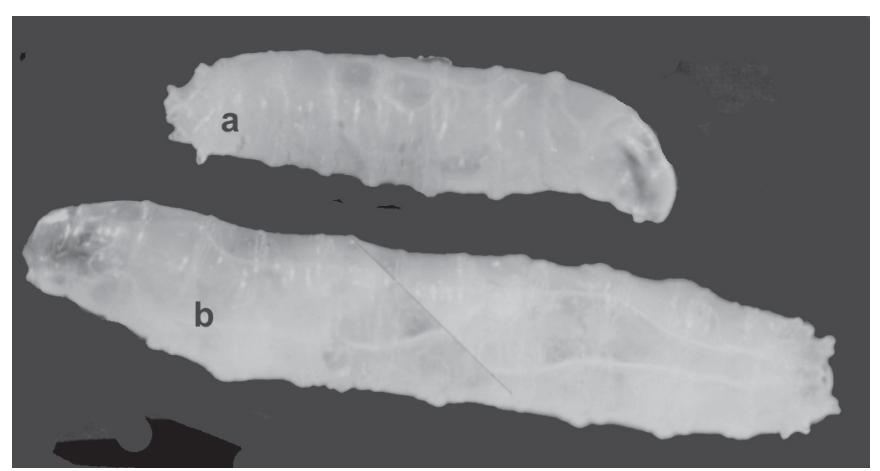

a. on SDM (control = medium no 1); b. on 100\% SCP (medium no IX).

Figure 1. Third instar larvae of D.melanogaster X 31.25.

Table 4. The effects of SCP on the number of offspring of $D$. Melanogaster.

\begin{tabular}{|c|c|c|c|c|c|c|c|}
\hline \multirow[t]{2}{*}{ Medium } & \multicolumn{2}{|c|}{ Male } & \multicolumn{2}{|c|}{ Female } & \multirow[t]{2}{*}{$\begin{array}{c}\text { Total } \\
\text { number of } \\
\text { individuals }\end{array}$} & \multicolumn{2}{|c|}{$\begin{array}{l}\text { Number of } \\
\text { abnormal } \\
\text { individuals }\end{array}$} \\
\hline & $\mathrm{n}$ & $(\%)$ & $\mathrm{n}$ & $(\%)$ & & $\mathrm{n}$ & $(\%)$ \\
\hline I & 370 & 48.1 & 400 & $51.9^{*}$ & 770 ** & 5 & 0.64 \\
\hline II & 800 & 51.6 & 750 & $48.4^{*}$ & $1550^{* *}$ & 3 & 0.19 \\
\hline III & 790 & 51.3 & 750 & $48.7^{*}$ & $1540^{* *}$ & 3 & 0.19 \\
\hline IV & 1090 & 50.0 & 1090 & $50.0^{*}$ & $2180^{* *}$ & 2 & 0.09 \\
\hline V & 1173 & 51.0 & 1127 & $49.0^{*}$ & $2300 *$ & 1 & 0.04 \\
\hline VI & 1840 & 48.9 & 1920 & $51.1^{*}$ & $3760 *$ & 1 & 0.02 \\
\hline VII & 2047 & 48.9 & 2143 & $51.1^{*}$ & $4190^{*}$ & - & - \\
\hline VIII & 2100 & 48.8 & 2200 & $51.2^{*}$ & $4300^{*}$ & - & - \\
\hline IX & 2510 & 49.6 & 2550 & $50.4^{*}$ & $5060 *$ & - & - \\
\hline
\end{tabular}

* Sex-ratio difference is not significant $(\mathrm{P}>0.05)$; ** The increment of the total number of offsprings is significant $(\mathrm{P}<0.01)$. (abnormalities: 0.02-0.19\%) as they were not observed at the media with higher concentrations of SCP (Media VII, VIII and IX).

At the beginning of this work, we supposed that the SCP would have had a toxic effect on the growth of D. melanogaster, but we were surprised to find that it had a beneficial effect on this species at higher concentration. P. chrysosporium is a well-known white-rot fungus, which is known to be capable of degrading chlorinated organics that exist in bleaching effluents from pulp and paper mills (18), and large quantities of fungal biomass can cheaply be obtained from such processes (15). As seen in Tables 2 and 3 , the biomass is rich in inorganic and organic materials, especially for essential amino acids. The promoting effect of biomass on the growth may be due to the presence of some growth factors in it. Some phenotipic abnormalities observed in control (Medium I) support this idea. On the other hand, thermotolerant microorganisms such as $P$. chrysosporium have the same advantages as a source of single cell protein when compared with mesophilic microorganisms. The cost of energy is greatly reduced because: a) the energy required for heating is not as high as that required for refrigeration of the culture broth; b) Sterilization of the medium is not required due to the high temperature of the organism growth (16). In addition, the utilization of $P$. chrysosporium as a source of SCP for rats was found to be very promising. Because of the above reasons, we preferred the $\mathrm{SCP}$ of $P$. chrysosporium for this research.

Consequentlly, we can suggest that the SCP of $P$. chrysosporium has a promoting effect on the growth of $D$. melanogaster and can be used instead of corn flour in SDM. The mechanism of this growth promoting effect needs to be investigated both for D. melanogaster and for other Diptera.

\section{RESUMO}

\section{Efeito de biomassa como fonte de proteína no cultivo de Drosophila}

Investigou-se os efeitos de biomassa de Phanerochaete chrysosporium em diferentes concentrações $(1 ; 2,5 ; 5 ; 10 ; 25 ; 50$; 75 e 100\%) no crescimento de Drosophila melanogaster. Em meio SDM (Standard Drosophila Medium) a biomassa foi empregada como fonte de proteína, em substituição à farinha de milho. Observou-se que a biomassa causou aumento no tamanho corporal das larvas e no número de descendentes, especialmente nas concentrações mais elevadas (50, 75 e 100\%). Ao usar-se a concentração de $100 \%$, a metamorfose acelerou-se e completou-se um dia antes do controle. Foram observadas anormalidades fenotípicas tanto no meio controle $(0,64 \%)$ quanto no meio contendo baixas concentrações de biomassa $(0,02$ a $0,19 \%)$, mas essas anormalidades não foram observadas na concentração de $100 \%$.

Palavras-chave: biomassa, toxicidade, Drosophila, Phanerochaete chrysosporium. 


\section{REFERENCES}

1. Algur, O.F.; Gokalp, H.Y. Batch culture of Rhizopus arrhizus and Actinomucor elegans on vinasse medium for biomass production and BOD reduction. Doga Tr. J. Biol., 5: 198-205, 1991.

2. Anupama, P. Value-added food: Single cell protein. Biotechnol. Advances, 18: 459-479, 2000.

3. AOAC, Official Methods of Analysis. $11^{\text {th }}$ ed. Association of Officia Analytical Chemists, Washington, D.C., 1970.

4. Cole, R.; Kirksey, J.W.; Moore, J.H.; Blankenship, B.R.; Diener, U.L.; Davis, N.D. Tremorgenic toxin from Penicillium verruculosum. Appl. Microbiol., 24: 248- 256, 1972.

5. Cole, M.; Rolinson, G.N. Microbiol metabolites with insectisidal properties. Appl. Microbiol., 24: 660-662, 1972.

6. Cardoso, M.B.; Nicoli, J.R. Single cell protein from termotolerant fungus Phanerochaete chrysosporium grown in vinasse. 1. Production and composition. Nutrition Reports International., 24: 237-246, 1981

7. Faust, U. Production of microbial biomass. In: Prave, P.; Faust, U.; Sitting, W.; Sukatsch, D.A. (eds.), Fundamentals of Biotechnology. Weinhelm: VCH Publishers, 1987, p.601-622.

8. Frazier, W.C.; Westhoff, D.C. Food Microbiology. Tata McGraw Hill Publishing Company Limited, New Delhi, 1990, p.398-415.

9. Ghanem, K.M. Single cell protein production from beet-pulp by mixed culture. Microbiologia., 8(1): 39-43, 1992.
10. Hodge, S.; Mitchell, P. Inhibition of D. melanogaster and D. hydei by Aspergillus niger. Dros. Inf. Serv., 80: 6-7, 1997.

11. Kuzmanova, S.; Vandeaka, E.; Dimitrovski, A.; Doneva, D. Microbial procedure for utilization of food industry wastes. Dechema Biotechnology Conferences 3-VCH Vertagsgesellschaff, 1989, p.985988.

12. Saito, M.; Enomoto, M.; Tatsuno, T. In: Ciegler, A.; Kadis, A.; Aj1, S.J. (eds). Yellowed rice toxins, Academic Press, New York, 1971.

13. Scott, P.M.; Merrien, M.A.; Polonsky, J. Roquefortine and isofumigaclavine A,metabolite from Penicillium roqueforti. Experientia., 32: 140-142, 1976.

14. Silva, M.E.S.T.; Nicoli, J.R. Production and nutritive value of single cell protein from Fusarium oxysporum var. lini grown in vinasse. $J$. Ferment. Technol., 63: 91-94, 1985.

15. Sing, C.; Yu, J. Copper adsorption and removal from water by living mycelium of white-rot fungus Phanerochaete chrysosporium. Wat. Res., 32(9): 2746-2752, 1998.

16. Surucu, G.A.; Engelbrecht, R.S.; Chian, E.S.K. Thermophilic microbiological treatment of high strength wastewater with simultaneous recovery of SCP. Biotechnol. Bioeng., 17: 1639-1641, 1975.

17. Uysal, H.; Algur, O.F. Effects of Penicillium roqueforti on some growth parameters of Drosophila melanogaster. Dros. Inf. Serv., 83: 37-41, 2000.

18. Yetis, U.; Dolek, A.; Dilek, F.B.; Ozcengiz, G. The removal of Pb(II) by Phanerochaete chrysosporium. Wat. Res., 34(16): 4090-4100, 2000. 